\title{
CARBON TAX: PROGRESS OR PLATITUDE FOR SOUTH AFRICA?
}

\author{
By Michele N Dempster*
}

\section{Introduction}

In light of the 2009 United Nations Copenhagen climate change conference, ${ }^{1}$ South Africa announced that in order to combat climate change it would commit to reducing domestic greenhouse gas (GHG) emissions by 34 per cent by 2020 and 42 per cent by $2025 .^{2}$ Due to this commitment, a carbon tax will be implemented as from 1 January 2015. ${ }^{3}$ This market-based instrument has received broad attention sparking debate as industries most affected, namely Eskom and the petroleum sector, have rallied together in complaint. ${ }^{4}$ The main debate being that despite the politically ambitious commitment to reduce GHG emissions, little scientific, economic or comparative evidence has been given to show that an influence will actually be had on the amount of GHG emitted. ${ }^{5}$

The purpose of this article is not to provide a detailed analysis of the entire scope of the South African climate change policy. It focuses on the more limited issue of carbon taxation. This does not however mean that the numerous other competing policy options, which still beg for attention, are not viable or will not be implemented in the future. ${ }^{6}$

\subsection{What is a carbon tax?}

Carbon Tax is a pollution tax levied on businesses and industries that produce carbon dioxide through their operations. A carbon tax is aimed at reducing the amount of GHG emitted into the atmosphere.

Final Year LLB, University of Pretoria.

National Treasury Reducing Greenhouse gas emissions: the carbon tax option (2010) 4

National Treasury (n 1 above) 6.

National Treasury Reducing Greenhouse Gas Emissions and facilitating the transition to a green economy (2013) 11.

F Saliem 'The Carbon Tax Debate' Engineering Weekly 21 July 20131.

Saliem (n 4 above) 1

National Treasury (n 1 above) 15. 
GHG is any atmospheric gas that contributes to the greenhouse effect. $^{7}$ The main GHG contributing to such effect is carbon. Carbon is present in coal, petroleum, and natural gas; when burnt or used in production it is released as carbon dioxide. Carbon dioxide $\left(\mathrm{CO}^{2}\right)$ is a colourless, odourless, incombustible gas. 8

The carbon tax policy of a country is specifically designed to tax fossil fuel usage of an industry, individual or business according to the amount of carbon emitted by such role player. ${ }^{9}$ It can also be seen as a fixed charge or price placed on GHG emissions that are set by the government for certain sectors individually. Tax on these emissions can be levied by taxing the carbon content of fossil fuels at any point in the production cycle. 10

\section{South Africa's climate change policy and the development of a carbon tax}

A future with carbon tax is set in stone for South Africa. While, other options, such as renewable energy and energy efficient technology, have not yet made their way to the table and, yet further, programmes such as the Carbon Capture and Storage (CCS) are fast developing but yet to be considered. ${ }^{11}$ The progress from implementing a climate change policy to a carbon tax is thus discussed.

South Africa has long thought itself a leading African country in international climate negotiations. ${ }^{12}$ The earliest indication of South Africa taking action towards climate change was at the Climate Change Convention held in Bali, in November and December 2007. ${ }^{13}$ A series of conferences and other measures took place after the Bali convention, namely: ${ }^{14}$

- Long Term Mitigation Strategy Scenarios (2008);

- South African Climate Change Policy Summit (March 2009);

- Green Economy Summit (May 2010);

- National Climate Change Response Green Paper (November 2010); and

7 The phenomenon whereby the earth's atmosphere traps solar radiation caused by the presence in the atmosphere of gases such as carbon dioxide, water vapour, and methane that allow incoming sunlight to pass through but absorb heat radiated back from the earth's surface.

$8 \quad$ N Wallart The political economy of environmental taxes (1999) 54-61.

9 R Hagemann 'Fiscal consideration: what are the best policy instruments for fiscal consideration' (2012) OECD Economic Journal 93.

10 Baumol \& Wallace The use of price and standards for protection of the environment (1971) 42.

11 National Treasury (n 3 above) 21.

12 National Treasury (n 1 above) 15.

13 National Treasury (n 1 above) 16.

14 National Treasury (n 3 above) 32. 
- National Climate Change Response White Paper (NCCRP) (November 2011).

The Department of Environmental Affairs (DEA) issued the 2011 White Paper stating a coordinated and consistent policy framework that addressed climate change issues. The DEA had the intention of aligning and contextualising climate change efforts. ${ }^{15}$ The aim stated was to 'effectively manage the negative impact of climate change by adopting policy interventions'. ${ }^{16}$ This requires the need to adapt processes, systems and approaches that mitigate climate change as well as build technology, gather financial resources and develop monitoring and evaluation systems. ${ }^{17}$ Carbon tax became the leading initiative to realise these goals. During the 2013 budget speech, Minister of Finance, Pravin Gordhan, announced that a carbon tax would come into effect as from 1 January 2015.

\subsection{Structure and design of the South African carbon tax}

The National Treasury has stated that the main objective of implementing carbon taxes is to alter future behaviour and in doing so, lower GHG emissions. ${ }^{18}$ To begin with, a relatively low carbon levy will be charged with the intention to raise the levy progressively after five years, thereafter this levy will be significantly raised after ten years and so on. ${ }^{19}$ Supposedly this approach gives major carbonemitting industries the opportunity to invest in greener technologies and lower their GHG emissions in a gradual manner. ${ }^{20}$

A carbon tax will work to encourage producers and consumers to change their behaviour in three ways. ${ }^{21}$ Firstly, carbon pricing forces a shift in production and consumption patterns that are low-carbon and energy efficient driven. ${ }^{22}$ This is done by raising prices of goods and services based on the amount of the emission necessary to produce the related goods or services. ${ }^{23}$ The higher the price the less likely a consumer is to purchase such goods or services. ${ }^{24}$ Secondly, factors influencing production, goods and services that have high emissions will be replaced with low carbon-emitting alternatives in order to keep costs down and save money. ${ }^{25}$ Lastly, carbon taxing (2010) 18.

Department of Environmental Affairs and Tourism (n 15 above) 18.

Department of Environmental Affairs and Tourism (n 15 above) 14

National Treasury (n 3 above) 32.

As above.

National Treasury (n 3 above) 33.

As above.

As above.

As above.

National Treasury (n 3 above) 34.

As above.

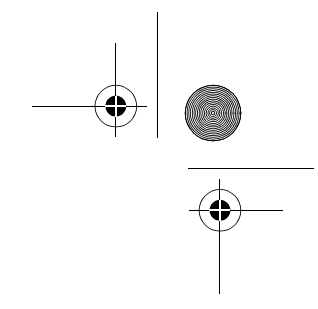

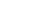


should allow for motivation to invest in research and development of technology that allows for low-carbon alternatives. ${ }^{26}$

GHG emitters will initially pay a levy of R120,00 per tonne of $\mathrm{CO}^{2}$ emitted and the intention is to increase this by $10 \%$ each year starting from 2015 and ending in 2019. From 2020 onwards no rates have been discussed and the National Treasury stated that further investigation will be done on the matter at a later stage. ${ }^{27}$

To start with, a $60 \%$ across-the-board tax-free threshold will be created and a further $10 \%$ reduction will be offered to certain sectors that cannot necessarily provide for technical and structural reductions in their emissions. These sectors include the iron and steel sectors as well as the cement and glass sectors. Agricultural and waste sectors will be completely exempt from carbon taxes. This exemption will possibly be reviewed after 2019 as yet the Treasury has given no definitive answer. The electricity sector, namely Eskom, will qualify for a $70 \%$ tax-free threshold and the petroleum sector will qualify for a tax-free threshold of up to $90 \%{ }^{28}$

When calculating this mathematically, industries mentioned (apart from the agricultural and waste sectors - who will be entirely exempt) the actual per tonne levy for GHG emitted is between R 12,00 and $R$ 48,00.

\subsection{Effectiveness of a carbon tax}

Despite any advantage or disadvantage a carbon tax may hold, and notwithstanding the possibility of a perfect carbon tax design or even perfect implementation, the most important question is whether the object of introducing a carbon tax will be fulfilled. Government's main objective for introducing a carbon tax is to lower GHG emissions thus transforming South Africa into a low-carbon economy as per the climate change policy of the country. ${ }^{29}$

Norway has had a carbon tax system in place for over a decade now, implementing a high carbon tax since 1991. ${ }^{30}$ The Norwegian taxes are one of the highest in the world and extensive research conducted has shown that carbon tax has had little effect on emissions. ${ }^{31}$ The Treasury has suggested a similar set up whereby some industries are taxed and others are not. In Norway, industries that were taxed on emissions showed an average of $1.5 \%$ decrease in

As above.

As above.

National Treasury (n 3 above) 35.

Department of Environmental Affairs and Tourism (n 15 above) 7.

$M$ Anderson Environmental and economic implications of taxing and trading carbon: Some European experiences (2008) 3.

31 Anderson (n 30 above) 3. 
CO2 emissions. ${ }^{32}$ With industries not taxed at all, an average increase of $18.7 \%$ in emissions has been recorded. ${ }^{33}$ If Norway has a far higher tax levy resulting in very little change in emissions, can it be said that a smaller tax levy would affect any change in South Africa?

The difference will be found in what government decides to do with the revenues; a question the National Treasury is yet to answer.

Potential recycling measures - through either the tax system or expenditure - will be explored. The most common implementation of revenue recycling is to reduce employers' social security contributions or income taxes in compensation. Reductions in corporate taxes are unusual and there are no examples of reductions in indirect taxation such as value-added tax. Both ex ante and ex post studies analysing the impact of environmental tax reform with recycling tend to find positive impacts on employment and output. ${ }^{34}$

At the Centre for the Study of Science at the libertarian think tank, the Cato Institute, a recent study found that an increase in global average temperature was about 3 degrees Celsius in the past decade. ${ }^{35}$ The study showed that if the United States of America (USA) were to somehow completely eliminate all its GHG emissions, the result in the future would be a mere 0.2 degree Celsius decrease by 2100.36

Such results discourage industries and make them question why such a tax should be implemented if little change is affected. ${ }^{37}$ Surely, if such a minimal difference is made then introducing a carbon tax will not fulfil the South African government's aim and ultimately, it will not fulfil the climate change policy of the country. The opposing side to such debate however, is the fact that the research done on the USA did not include a global action to combat climate change. No research has been done on the effect should the USA and, for example, China eliminate all their GHG emissions. ${ }^{38}$

In finding a better way to observe the necessity for a carbon tax in South Africa one could look at the 'Tragedy of the Commons'.39 This is a concept based on ecologist Garrett Hardin's idea that there is a pasture open to all. Animals graze in the pasture. Men continue to add animals to the pasture because the more animals they have the more wealth they generate. However, the more animals they add to the pasture, the more the pasture begins to deteriorate. Although

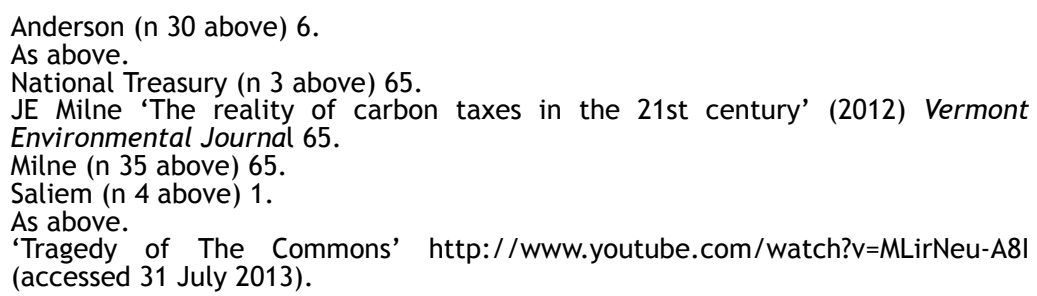


each animal added only degrades the pasture a small amount, added all together there is eventually no pasture left at all. When applying this concept to that of pollution, society is affected by the resulting pollution of all GHG emitting industries combined. When looking at one firm or company on its own little impact or damage is seen, however, when combining the overall impact the result is devastating. Thus, just as each country has seemingly contributed a small amount - or one extra animal - in order to increase their wealth, they must now withdraw that small amount so that a combined reduction will allow for greater impact. Put in another way, it would not help to only tax the biggest contributor in South Africa for example Eskom - as this will only allow for a few 'animals' to leave the pasture.

\section{Problems with the carbon tax design}

Government has a general belief that a carbon tax will have a considerable and pioneering effect on the amount of GHG emitted. ${ }^{40}$ When taking into account the exemptions proposed by government for certain fossil fuel-intensive industries, very few actual levies end up being paid. ${ }^{41}$ The industries that one would expect a carbon tax to target are in fact the industries that will be exempted and allowed 'off-sets' ${ }^{42}$ Of course the exemptions are necessary, according to government, in order to curb the worry that these industries will lose competitiveness in the domestic, as well as the international market. ${ }^{43}$

When looking at it plainly, if the metal sector and industrial chemicals sector are not exempted from carbon tax, a large amount of companies within these sectors will become unprofitable. ${ }^{44}$ Similarly, if the fishing and sea transport sectors are not exempted then economic analysis suggests a reduction in production level. ${ }^{45}$ Agricultural and waste sectors have been completed exempted from paying carbon taxes for the first few years, with the intention of reviewing such policy in the future. ${ }^{46}$ It seems redundant then if those actually being taxed for carbon emissions are not the only contributors, and moreover are not the main contributors.

Carbon tax is a relatively good concept and can encourage behavioural change; however it seems less likely that a carbon tax is

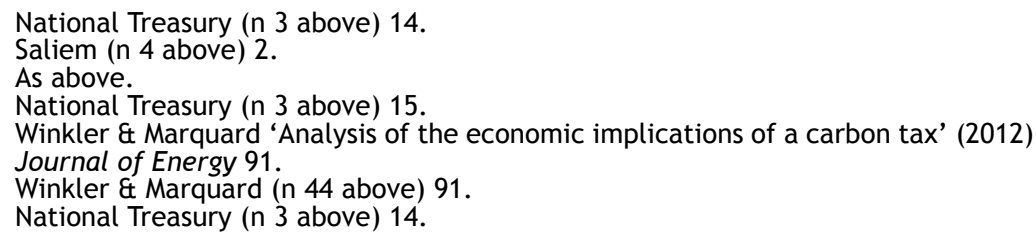


going to succeed in South Africa. ${ }^{47}$ The impact on the economy appears negative due to the fact that South Africa has high carbon intensity, mostly coming from a state-owned entity (Eskom). ${ }^{48}$ It is never a good idea to implement policy that will clearly drive away investment. ${ }^{49}$ Doing nothing at all, however, is not possible and when considering the alternatives carbon tax appears nearly perfect.

\subsection{Alternative}

Cap-and-trade is the only other viable instrument that can be considered in South Africa. It is a regulatory instrument that limits or 'caps' the amount of carbon emissions and pollution allowed per company. Companies are then permitted to sell or 'trade' the portion they have not used to other companies that have been unable to comply or are struggling to do so. Under this form of environmental protection, the idea is to reduce certain kinds of emissions and pollution and to provide companies with a profit incentive to reduce their pollution levels. ${ }^{50}$

Theoretically, a cap-and-trade system achieves similar results to a carbon tax and ultimately has the same aim. ${ }^{51}$ However, the conditions necessary to allow for a cap-and-trade system to succeed are a lot more involved and require certain challenges to be overcome before any implementation can take place. ${ }^{52}$ Cap-and-trade systems require the allocation of permits, as well as a new set of financial regulations to which industries must adhere. ${ }^{53}$ In any case, cap-andtrade will cause tax implications as it is possible for income to be earned from the trading of excess emissions. ${ }^{54}$

A carbon tax thus seems more appropriate when trying to put a price on carbon. ${ }^{55}$ The design of a carbon tax is also fairly easy to understand and model. ${ }^{56}$ Although many arguments are made against the measuring of GHG emissions in a carbon tax system, a similar form of measurement would also be used in a cap-and-trade system. ${ }^{57}$ With a carbon tax, the tax levy is gradually introduced allowing time for the taxpayer to adjust. ${ }^{58}$ Cap-and-trade systems require immediate

Saliem (n 4 above) 2.

Eskom is a state-owed entity that is an electricity producing facility.

C Arndt 'Measuring the carbon intensity of the South African economy' (2013)

South African Journal of Economics 55.

Milne (n 35 above) 65.

Saliem (n 4 above) 3.

Anderson (n 30 above) 5.

Anderson (n 30 above) 4.

Anderson (n 30 above) 3.

Saliem (n 4 above) 2.

As above.

Anderson (n 30 above) 4.

National Treasury (n 3 above) 16. 
adjustments in order to correctly measure and trade emissions. ${ }^{59} \mathrm{~A}$ large portion of the industries in South Africa would be unable to allocate revenue to the cost of the adjustments necessary in a capand-trade system. ${ }^{60}$ With regard to the competitive concerns, many sectors are being afforded offsets, tax reductions or are in fact zero rated to begin with. ${ }^{61}$ Both options are viable for South Africa and in an ideal economy both could be applied simultaneously (thus allowing for a hybrid system). ${ }^{62}$

\section{Conclusion}

It seems apparent that a well-structured carbon tax may result in some form of GHG emission reduction. With the development of a carbon tax in South Africa having taken place over a period of three years, Government has had more than enough time to correctly structure and model a perfectly suited carbon tax. Many questions are still left unanswered as to what will happen after the implementation of the carbon tax. The important crux of the information given, however, is that such a carbon tax is in line with South Africa's climate change policy; that being to reduce GHG emissions and transform South Africa into a low-carbon economy. Whether South Africa's reduction in GHG emissions makes little difference in global warming or perhaps no difference at all, it is important that it remains a role player in the international action towards mitigating climate change. ${ }^{63}$

Anderson (n 30 above) 4.

Anderson (n 30 above) 6.

National Treasury (n 3 above) 65.

Arndt (n 49 above) 55.

United Nations Gateway to systems work on climate change policy (2010) 2. 